\title{
The biodiversity data knowledge gap: assessing information loss in the management of Biosphere Reserves
}

\author{
Andrea Pino-Del-Carpio, Arturo H. Ariño*, Ana Villarroya, Jordi Puig, Rafael Miranda \\ Department of Zoology and Ecology, University of Navarra, Irunlarrea 1, E-31008, Pamplona (Navarra), Spain \\ * Corresponding author: Arturo H. Ariño, Department of Zoology and Ecology, University of Navarra, Irunlarrea 1, \\ E-31008, Pamplona (Navarra), Spain. Telephone: +34 948425600 x 806296. E-mail address: artarip@unav.es
}

\begin{abstract}
The knowledge of biodiversity within an area is vital if we want to develop adequate conservation strategies. Biosphere Reserves are purposefully established for the sustainable use of their resources, and therefore their biodiversity should be well known. We compared and evaluated information available for Mexican Biosphere Reserves on threatened and non-threatened vertebrate species records from three different sources--the corresponding Biosphere Reserves management plans (MPs), the Global Biodiversity Information Facility index (GBIF), and scientific literature, in order to find potential knowledge gaps. Our results suggest that there were varying gaps in information among sources according to vertebrate group. For each group of vertebrate species, management plans held the largest subsets of information but were not complete, ranging from $89.6 \%$ of the combined known species of birds to $70 \%$ for amphibians and freshwater fishes. However, both GBIF and literature included data absent from MPs, and GBIF included data not otherwise available, proving it as important as literature or other data sources (e.g. field data) used for crafting such plans. Moreover, we found references to threatened species that were not listed in the MPs, reaching to as many as $50 \%$ of the total known species of fish. Species information shared by all three sources ranged from $28 \%$ for amphibians to $72.5 \%$ for birds. Conservation efforts should therefore take into account that possibly less charismatic taxa such as amphibians, reptiles and freshwater fish lack more information than birds or mammals. The disparity observed in the vertebrate species information constitutes an information gap that could (or should) be solved by scientists and managers alike.
\end{abstract}

Keywords: Biosphere Reserves, GBIF, management plans, Mexico, literature data, vertebrates. 


\section{Introduction}

Over the past decades, biodiversity, defined by the diversity of genes, populations, species, communities and ecosystems, is assumed to be disappearing at an unprecedented rate (Butchart et al., 2010; Rands et al., 2010). The cause of this decline is the increasing development of human activities and their potential impacts, such as land conversion, invasion by exotic species, pollution, and climate change (Lawler et al., 2006) among others. It seems therefore imperative to establish priorities and take precise decisions to mitigate these losses.

An early step to protect this biodiversity was the establishment of protected areas, among which Biosphere Reserves were created with the aim of reconciling biodiversity conservation with the sustainable use of the resources contained within. We should thus assume that the knowledge of their biodiversity would be high, which make them sites of excellence to explore and demonstrate approaches to conservation (UNESCO, 1996). However, to our knowledge the extent to which biodiversity within these sites is known had not yet been assessed.

Therefore, we decided to evaluate the knowledge of vertebrate species occurrence in Mexican Biosphere Reserves. Mexico has the third highest number of Biosphere Reserves (41) in the world and has made freely available all documents about their management plans (CONANP, 2011; INE, 2011). Moreover, Mexico has excellent information about its biodiversity. We focused on species richness, as ecosystem-level or genetic diversity, much harder to measure, have yet to produce a comparable body of data.

We assessed the records of vertebrate species within Biosphere Reserves' Management Plans (MPs) with the aim of detecting gaps in the information available in alternative sources of information like existing literature and the databases shared through the Global Biodiversity Information Facility (GBIF, 2013), and to expose the implications of these gaps in the management and conservation of species within the reserves. A previous research carried out in freshwater fish species within Mexican Biosphere Reserves, demonstrated that there is indeed a communication gap among these sources of information (Pino-del-Carpio et al., 2011).

Management plans are documents that should identify administration necessities and resources, highlighting specific actions to direct and control the conservation and sustainable use of natural resources (Ortega-Rubio and Arguelles-Méndez, 1999). In turn, scientific literature is an accessible source of information which provides a record of scientific progress (Lawler et al., 2006). Finally, GBIF facilitates access to nearly $4 \mathrm{x}$ $10^{8}$ specimen or observation records (GBIF, 2013) existing in databases in many countries and institutions (Arzberger et al., 2004) that have decided to publish them. GBIF mobilises the data through a common portal, covering an ever-increasing fraction of all existing data (Ariño, 2010) and including vast amounts of georeferenced records (Soberón et al., 2007). One important set of databases sharing data through GBIF in the context of our work is that of the Mexican National Biodiversity Knowledge and Use Commission (Comisión Nacional para el Conocimiento y Uso de la Biodiversidad, CONABIO).

We focused on vertebrates, as they are perhaps one of the best known groups besides plants in terms of biodiversity and their pressures are relatively well known. While onefifth of all vertebrate species are increasingly being threatened, a trend only partially 
curbed by conservation efforts (Hoffmann et al., 2010), many vertebrate species (such as fish and mammals used for food or sport) are important resources for the livelihood of people (Hawksworth and Bull, 2007). Therefore, assessing what vertebrate species are actually present in biosphere reserves could help direct conservation efforts that take into account how they are used.

Among vertebrate species, amphibians are more threatened than birds or mammals (Stuart et al., 2004) while reptiles, although poorly studied at least in the context of protected areas (Koleff et al., 2009), are equally or more threatened than amphibians, as they suffer from, and are vulnerable to, the same types of threat (Gibbons et al., 2000; Gardner et al., 2007). Both groups account for about a quarter of all the vertebrate species in the world (IUCN, 2011) but they are less studied worldwide than birds or mammals (Gardner et al., 2007; Urbina-Cardona, 2008) in spite of their vulnerability to habitat degradation (Koleff and Urquiza-Haas, 2011).

Freshwater fish are under threat as a result of human disturbance in freshwater habitats (Saunders et al., 2002; Clavero, 2011) and their study is important, as they are good indicators of the health of the environment (Hermoso et al., 2010). Additionally, freshwater fish are vulnerable to the effects of pollution, disease, and introduction of non-native species among others (Allan and Flecker, 1993); similar threats, and some others such as hunting, have been also reported for birds (Naranjo and Dirzo, 2009).

\section{Methods}

\subsection{Study design}

We drew information on vertebrate species in the Biosphere Reserves from their MPs. These plans were obtained from the WebPages of Mexican Administration (Instituto Nacional de Ecología (INE, 2011) and Comisión Nacional de Áreas Naturales Protegidas (CONANP, 2011) (Table A1). The various plans included lists of species compiled from a wide variety of sources, including (but not limited to) inventories and catalogues, field work, monitoring reports, scientific papers, or distribution estimations.

Independently from MPs, literature data was harvested from ISI Web of Knowledge (Thomson Scientific, 2009), Google Scholar, other databases, other literature, and authors. A full list of reviewed literature is given in List A4.

Information retrieved from GBIF-mediated databases was acquired using the geographic coordinates provided as a bounding box in MPs or in the UNESCO's Biosphere Reserve database (UNESCO, 2011).

To ensure that georeferenced records fell within the areas of interest, boxes were checked against the actual shape files of the Reserves in .shp format provided by CONANP using ArcView 9.1. In cases where the bounding boxes did not enclose the shape files, the boundaries were extended by a small buffer zone to ensure full coverage of each Reserve's area, following Pino-del-Carpio et al. (2011). Records with coordinates falling either outside the buffer zones or outside the boundaries of the reserves were discarded. This conservative method discarded potentially valid records, but increased the quality of the remaining ones. 
Each of the three sources (MPs, GBIF and literature) produced a different list of vertebrate species for every Reserve. These lists were combined into one single dataset, where we identified the source(s) of the vertebrate species records. We then analysed the number and extent of coincidences among sources and tabulated the species mentioned in one, two, or all three sources.

We also produced summary data of the vertebrate species lists taken separately (e.g. average number of species in the reserves according to each source).

\subsection{Taxonomic review}

A taxonomic review was carried out on the species lists, and scientific names were validated according to the W. N. Eschmeyer's Catalog of Fishes (Eschmeyer, 2011), International Ornithological Congress (Gill and Donkster, 2012), Birdlife International (Birdlife, 2012), Mammals Species of the World (Wilson and Reeder, 2005), The Reptile Database (Uetz et al., 2007) and Amphibian Species of the World (Frost, 2011).

\subsection{Threat status of species}

We consulted the International Union for Conservation of Nature (IUCN) Red list (IUCN, 2011) and Mexican Standard Normative (Diario Oficial de la Federación, NOM-059-SERMANAT-2010), which list wildlife species under a category of risk, to find catalogued species and their conservation status with the aim to discuss the MPs from a conservation point of view.

\section{Results}

\subsection{Sources of information}

As stated by the Mexican National system of protected areas (SINANP), there are 41 Biosphere Reserves in Mexico. We selected 25 for the analysis of birds, mammals, amphibians and reptiles and 21 for the analysis of fish. Eight biosphere reserves were not eligible because of lack of MPs or because a list of the species recorded in the area was not available (four in the case of freshwater fishes). Regarding scientific literature, we reviewed 197 papers. Searches in GBIF-mediated databases produced 68,929 occurrence-based records, which represented 1,776 species for all taxa. After analyzing the species data obtained from the three sources of information, we worked with 3,598 records for mammals, 14,368 for birds, 2,170 for reptiles, 1,369 for fishes and 821 for amphibians.

For each group of vertebrates, the most extensive information on species presence came from the management plans although at different rates according to the taxonomic group.

\subsection{Biosphere Reserves}

When all Biosphere Reserves are taken as a whole (i.e. data from all reserves are pooled together), MPs accounted for $89 \%$ of bird species know to occur in Biosphere Reserves, $81 \%$ of mammals, $80 \%$ of reptiles, $70 \%$ of amphibians and $70 \%$ of fish. In the case of both GBIF network and literature, these percentages also differed according to the group of vertebrate (Fig.1). Therefore no single source accounted for all species recorded in the analysed taxa. 
In addition, each independent source revealed from $2 \%$ to $15 \%$ of species unknown to any of the other two sources according to the taxon group. All three sources shared from $28 \%$ (amphibians) to $73 \%$ (birds) of species (i.e. those appearing simultaneously in the MPs, GBIF and scientific literature).

However, individual reserves had much larger variability and less commonality among sources (Table A2). On average, individual reserves' MPs accounted for $72 \%$ of birds known to occur in Biosphere Reserves, $74 \%$ of mammals, $68 \%$ of reptiles, $63 \%$ of amphibians and $58 \%$ of fish. Also on average, each independent source revealed from $6 \%$ to $29 \%$ of the total number of species of any given reserve, depending on the vertebrate group. The highest values of species richness found in just one source of information were for reptiles (in MP's) and the lowest for birds (in literature). Notably, amphibians and freshwater fishes were the groups appearing most selectively in literature sources. Furthermore, the percentage of shared information among sources varied across vertebrate group. It is highest for birds (17\%) and lowest for reptiles (6\%).

\subsection{Threatened species}

The results obtained from the Mexican standard normative NOM-059-SERMANAT2010 and from the IUCN red list of threatened species, indicate that amphibians and reptiles are the most threatened groups. At the same time, freshwater fishes and amphibians are the groups that are poorly represented in the management plans (Fig. 2; Table A3).

\section{Discussion}

A coherent first step to conserve biodiversity is to have the most accurate knowledge of the diversity that occurs in and area and assess its status (Maddock and Samways, 2000). In this context Biosphere Reserves, considered as learning laboratories (Ishwaran and Persic, 2008), are ideal places to evaluate the knowledge of its biodiversity. Indeed, Target 11 of the Convention on Biological Diversity (CBD)'s Biodiversity Targets calls for conservation of areas of particular importance for biodiversity (UNEP, 2010), and assessment of conservation requires some explicit measurement of biodiversity coverage by protected areas (Faith et al., 2013). Our work contributes towards this target by identifying knowledge gaps in these places, taking Mexico as a case study.

There are eight Biosphere Reserves in Mexico that lack both management plans and a vertebrate species list (out of 33 terrestrial Biosphere Reserves in the entire country). The lack of information about the management and biodiversity contained within a Biosphere Reserve hamper the development of proper conservation strategies for the area. The absence of records on vertebrate species may also have an impact on endemic species (in fact, one important criterion in Mexican law to establish a Biosphere Reserve is the protection of endemic species and their habitats: Diario Oficial de la Federación, 1988 and 2012).

It comes as no surprise that freshwater fish, reptiles and amphibians are the classes of the targeted vertebrates less recorded in management plans. In fact, in Mexico, even though the vertebrate species are well known, the knowledge is diverse and unequal (Llorente-Bousquets and Ocegueda, 2008). Research for amphibians, reptiles and some mice species is still needed (Llorente-Bousquets et al., 2008). The difference in vertebrate knowledge might happen because most of the research developed in conservation biology is mainly constituted by studies on birds and mammals whereas studies in reptiles, amphibians and fishes are underrepresented (Clark and May, 2002; 
Fazey et al., 2005): According to Koleff and Urquiza-Haas (2011), March and others in 2009 had compiled 95 strategic planning reports published over 15 years on biodiversity conservation in Mexico, with almost half of them oriented to wildlife and habitat conservation of which one-third focused on mammals and birds.

Amphibians and reptiles show higher threat status and have more species at risk when compared to mammals and birds (Gardner et al., 2007). Both amphibians and reptiles are important components of biodiversity and are good indicators of the environmental quality. In Mexico, reptiles and amphibians are key groups for conservation because of their high level of endemism. Around $60 \%$ or amphibian and $50 \%$ of reptile species occur only in Mexico (Conabio et al., 2007). They play significant roles in food webs, as predators, preys, herbivores, and carnivores (Blaustein and Wake, 1995; Urbina-Cardona, 2008). Moreover amphibians experience both aquatic and terrestrial stages (eggs, larvae and adult) in their lives which make them vulnerable to any stressor in the environment (Blaustein and Kiesecker, 2002).

Some explanations to the relatively lesser interest in the study of these groups may arise, in the case of reptiles, from the fact that they are organisms with small population sizes and cryptic habitats, which make them difficult to observe in the wild (UrbinaCardona, 2008). On the other hand, amphibians are noticeable due to large breeding aggregations but their populations fluctuate annually in size (Collins and Storfer, 2003) which makes it hard to accurately evaluate their conservation status. Furthermore, amphibians and reptiles have the disadvantage of having an expensive and non-effective standardized sampling methodology, which sometimes restrains the study of these organisms towards other species easier to survey (Gardner et al., 2007).

It should be noted that $74.2 \%$ of amphibian and $81.7 \%$ of reptile species occur in Mexican protected areas, but when the analysis is restricted only to endemic species, only $29 \%$ of amphibians and $46 \%$ of reptile species have been listed within a protected area (Koleff et al., 2009).

In the case of freshwater fishes, the reasons for being less studied than other classes may lie in the fact that they are difficult to observe in the wild, and because they are not as attractive as birds or mammals (Darwall et al., 2008). Even though conservation organizations carry out an important activity in data compilation, the observed bias on the information can be due to the focus of their funding and research mostly in birds and mammals (Clark and May, 2002).

Even though birds and mammals seemed to be well represented in Biosphere Reserves MP's ( $89 \%$ and $81 \%$ of the total number of species respectively), there are still some issues that have to be solved for these groups in protected areas. For instance, there is a lack of biogeographical region representativeness in the current Mexican protected areas, which makes it difficult to consider endemic mammal species, or species that have restricted geographic ranges inside protected areas (Ceballos, 2007). In this regard, Koleff et al. (2009) published that 11 out of the 96 Mexican eco-regions do not include any protected area, while 50 are underrepresented. In their study, the coverage of different altitudinal zones was also evaluated. The results showed that 19 altitudinal zones have at least $12 \%$ of its territory protected. On the other hand, 10 altitudinal zones in the ranges -49 to $0,400-600$ and 1000-2600 $\mathrm{m}$ a.s.l. (representing $55.5 \%$ of all the Mexican territory) are conservation gaps. A bias to protect higher lands was also observed. The beta diversity in Mexico is high, with wide species change among regions and localities, and complete representativeness is difficult even for those of particular interest in conservation (Koleff and Urquiza-Haas, 2011). 
Regarding birds, they are the most studied group of vertebrate species in Mexico, in no small part benefiting from the extensive work of birdwatchers that collect data about bird ecology and distribution (Gómez de Silva and Alvarado-Reyes, 2010; Koleff and Urquiza-Haas, 2011). Moreover, birds are well represented in protected areas with around $96 \%$ - 98\% of all species preserved within them (Koleff et al., 2009).

Nevertheless, there are still some important areas for endemic and threatened bird species that are not protected: Koleff and Urquiza-Haas (2011) argue that lack of protected areas or alternate conservation schemas negatively impact effective conservation of birds and perhaps other biota in Mexico. Koleff et al. (2009) suggest that it would be necessary to extend up to $20 \%$ the network of protected areas to obtain a complete representation of all bird species.

Apart from this, the sampling plans for animals and plants have not been done uniformly throughout Mexico. There are areas that have been well sampled while others remain poorly studied. Among other possible reasons, this difference in sampling may be due to the location of the sites (Bojórquez-Tapia et al., 1995). Whereas areas surrounding accessible places are well sampled, sites that are far away from cities (which may only be accessed after a several days long trip), like mountainous areas, are less sampled (Llorente-Bousquets and Ocegueda, 2008). This phenomenon could be easily extrapolated to other countries and regions in the word.

The relatively high percentages of species found in just one source of information shown in our results demonstrate that the interchange of information among sources for Mexico may be improved, and render a better information base for species management within the Reserves. Although it can be argued that some of the literature may have appeared after the MPs were put in place and that GBIF started to facilitate data as recently as 2004 (Chavan et al., 2010), MPs should not be considered static and their information should be statutorily updated when it becomes available.

Scientists and managers may find in the GBIF-mediated databases a cost-effective way to enhance the biodiversity information they work with in order to efficiently manage the reserves (Pino-del-Carpio et al., 2011). Certainly the development of databases has been one of the greatest achievements to make available information about diversity to researchers, decision makers and public in general. The pioneers in Mexican biological databases are the Biology Institute, the National Institute on Biotic research, the Autonomous University of Mexico (UNAM)-Iztapalapa and the Faculty of Science of the UNAM (Toledo, 2010). However, since 1992 CONABIO has been in charge of this task for the entire country (Llorente-Bousquets et al., 2008).

Complementarily, scientific literature review should be taken into account as it presents a great degree of exclusivity for fishes, amphibians and reptiles.

The high percentage of threatened species that were not registered in management plans (up to $50 \%$ in freshwater fishes) makes difficult the identification of species whose conservation should be set as a priority, hampering the development of conservation strategies. The accurate knowledge of the species contained in a Biosphere Reserve is the basis whereupon managers can build adequate conservation strategies and actions that can protect species and reduce biodiversity loss, as observed by Hoffmann et al. (2010). In that sense it is important to reduce the uncertainty that managers have to deal with when they develop conservation strategies for protected areas such as Biosphere Reserves. One way to solve this problem is the improvement of monitoring programs which will give information about the ecosystem and the species contained within, ensuring that policies will be science-based (Williams, 2003). 
It is necessary to bear in mind that some of these vertebrate species are natural resources that can be, and actually are, exploited for the livelihood of Biosphere Reserves inhabitants. These resources may not only provide food and clothes for people, but also produce economic benefits (as it happens with aquaculture and skin sale for leather industry), not to mention the ecological importance of all species as pollinators, biological control agents, and storehouse of biomedical products (Mittermeier et al., 1992).

Our analysis shows that the species information in Biosphere Reserves management plans may be improved if alternative sources of information as GBIF database and scientific literature were consulted. We also suggest that for threatened species, monitoring programs and research about species threats should be dealt with in a much more detailed way if managers want to develop proper conservation strategies for these species in their respective management plans.

\section{Acknowledgements}

We thank César Sanchez Ibarra from CONANP (Mexico) for his valuable information about Biosphere Reserves. This study was funded by a fellowship from the Association of Friends of the University of Navarra. This study received support from project CGL2006-02844/BOS from the Plan Nacional de I+D+I (2004-2007), Dirección General de Investigación, Ministerio de Ciencia e Innovación, Gobierno de España, European Regional Development Fund (ERDF).

\section{Appendices A-D. Supplementary material}

Supplementary data associated with this article can be found, in the online version, at http://www.sciencedirect.com/science/article/pii/S0006320713003996\#MMCvFirst

\section{References}

Allan, J.D., Flecker, A.S., 1993. Biodiversity Conservation in Running Waters. BioScience 43, 32-43.

Ariño, A.H., 2010. Approaches to estimating the universe of natural history collections data. Biodiversity Informatics 7, 81-92.

Arzberger, P., Schroeder, P., Beaulieu, A., Bowker, G., Casey, K., Laaksonen, L., Moorman, D., Uhlir, P., Wouters, P., 2004. Promoting access to public research data for scientific, economic, and social development. Data Science Journal 3, $135-152$.

Birdlife International, 2011. IUCN Red List for birds [WWW Document]. URL http://www.birdlife.org/datazone/home

Blaustein, A.R., Kiesecker, J.M., 2002. Complexity in conservation: lessons from the global decline of amphibian populations. Ecol. Lett. 5, 597-608. 
Blaustein, A.R., Wake, D.B., 1995. The puzzle of declining amphibian populations. Sci. Am. 272, 52-57.

Bojórquez-Tapia, L.A., Azuara, I., Ezcurra, E., Flores-Villela, O., 1995. Identifying conservation priorities in Mexico through geographic information systems and modeling. Ecol. Appl. 5, 215-231.

Butchart, S.H.M., Walpole, M., Collen, B., van Strien, A., Scharlemann, J.P.W., Almond, R.E.., Baillie, J.E.M., Bomhard, B., Brown, C., Bruno, J., Carpenter, K.E., Carr, G.M., Chanson, J., Chenery, A.M., Csirke, J., Davidson, N.C., Dentener, F., Foster, M., Galli, A., Galloway, J.N., Genovesi, P., Gregory, R.D., Hockings, M., Kapos, V., Lamarque, J.-F., Leverington, F., Loh, J., McGeoch, M.A., McRae, L., Minasyan, A., Hernández Morcillo, M., Oldfield, T.E.E., Pauly, D., Quader, S., Revenga, C., Sauer, J.R., Skolnik, B., Spear, D., Stanwell-Smith, D., Stuart, S.N., Symes, A., Tierney, M., Tyrrell, T.D., Vié, J.-C., Watson, R., 2010. Global biodiversity: indicators of recent declines. Science 328, 1164-1168.

Ceballos, G., 2007. Conservation priorities for mammals in megadiverse Mexico: the efficiency of reserve networks. Ecol. Appl. 17, 569-78.

Chavan, V.S., Gaiji, S., Hahn, A., Sood, R.K., Raymond, M., King, N., 2010. State of the Network 2010: Discovery and publishing of the Primary Biodiversity data through the GBIF network. Global Biodiversity Information Facility Secretariat, Copenhagen.

Clark, J.A., May, R.M., 2002. Taxonomic bias in conservation research. Science 297, 191-192.

Clavero, M., 2011. Assessing the risk of freshwater fish introductions into the Iberian Peninsula. Freshwater Biol. 56, 2145-2155.

Collins, J.P., Storfer, A., 2003. Global amphibian declines: sorting the hypotheses. Diversity and distributions 9, 89-98.

CONABIO-CONANP-TNC-PRONATURA-FCF, UANL, 2007. Análisis y vacíos y omisiones en conservación de la biodiversidad terrestre de México: espacios y especies. Comisión Nacional para el conocimiento y uso de la Biodiversidad, Comisión Nacional de áreas naturales protegidas, The Nature ConservancyPrograma México, Pronatura, A.C., Facultad de Ciencias Forestales, Universidad Autónoma de Nuevo León, México.

CONANP, 2011. Comisión Nacional de Áreas Naturales Protegidas, México [WWW Document]. URL http://www.conanp.gob.mx

Darwall, W., Smith, K., Allen, D., Seddon, M., McGregor, G., Clausnitzer, V., Kalkman, V., 2009. Freshwater biodiversity: a hidden resource under threat, in: Vié, J.-C., Hilton-Taylor, C., Stuart, S.N. (Eds.), Wildlife in a Changing World: An Analysis of the 2008 Red List of Threatened Species. Gland, Switzerland, pp. 4353.

Diario Oficial de la Federación, 1988. Ley general de equilibrio ecológico y la protección al ambiente.

Diario Oficial de la Federación, 2010. NOM-059-SERMANAT-2010. Protección ambiental especies nativas de México de flora y fauna silvestres - Categorías de riesgo y especificaciones para su inclusión, exclusión o cambio - Lista de especies en riesgo. 
Diario Oficial de la Federación, 2012. Decreto por el que se reforman y adicionan diversas disposiciones de la Ley General del Equilibrio ecológico y la protección al ambiente y de la Ley general de desarrollo forestal sustentable.

Eschmeyer, W.N., 2011. Catalogue of Fishes electronic version (19 February 2010) [WWW Document]. URL http://research.calacademy.org/ichthyology/catalo/fishcatmain.asp

Faith, D. P., Collen, B., Ariño, A. H., Koleff, P. O., Guinotte, J. M., Kerr, J. T., \& Chavan, V., 2013. Bridging Biodiversity Data Gaps: Recommendations to Meet Users ' Data Needs. Biodiversity Informatics, 8(1), 41-58. Fazey, I., Fischer, J., Lindenmayer, D., 2005. What do conservation biologists publish? Biol. Cons. 124, 63-73.

Frost, D.R., 2011. Amphibian species of the World: an Online reference. Version 5.5. (31 January, 2011). Electronic Database accessible at http://research.amnh.org/herpetology/amphibia/index.html [WWW Document]. URL http://research.amnh.org/herpetology/amphibia/index.html

Gardner, T.A., Barlow, J., Peres, C.A., 2007. Paradox, presumption and pitfalls in conservation biology: The importance of habitat change for amphibians and reptiles. Biol. Cons. 138, 166-179.

GBIF, 2011. Global Biodiversity Information Facility (continuously updated) [WWW Document]. URL http://data.gbif.org

Gibbons, J.W., Scott, D.E., Ryan, T.J., Buhlmann, K.A., Tuberville, T.D., Metts, B.S., Greene, J.L., Mills, T., LEiden, Y., Poppy, S., Winne, C.T., 2000. The global decline of reptiles, déja vu amphibians. BioScience 50, 653-666.

Gill, F., Donsker, D., 2012. IOC World Bird Names (v2.11) [WWW Document]. URL http://www.worldbirdnames.org

Gómez de Silva, H., Alvarado-Reyes, E., 2010. Breve historia de la observación de aves en México en el siglo XX y principios del siglo XXI. Huitzil. Revista de Ornitología Mexicana 11, 9-20.

Hawksworth, David L.Bull, A.T., 2007. Vertebrate Conservation and Biodiversity. Springer.

Hermoso, V., Clavero, M., Blanco-Garrido, F., Prenda, J., 2010. Assessing the ecological status in species-poor systems: A fish-based index for Mediterranean Rivers (Guadiana River, SW Spain). Ecol. Indic. 10, 1152-1161.

Hoffmann, M., Hilton-Taylor, C., Angulo, A., Böhm, M., Brooks, T.M., et al., 2010. The impact of conservation on the status of the world's vertebrates. Science 330, 1503-1509.

INE, 2011. Instituto Nacional de Ecología [WWW Document]. URL http://www.ine.gob.mx

Ishwaran, N., Persic, A., 2008. Concept and practice: the case of UNESCO biosphere reserves. Int. J. Environment and Sustainable Development 7, 118-131.

IUCN, 2011. The IUCN Red List of Threatened Species. Version 2011.1 [WWW Document]. URL http://www.iucnredlist.org

Koleff, P., Tambutti, M., March, I.J., Esquivel, R., Cantú, C., Lira-Noriega, A., 2009. Identificación de prioridades y análisis de vacíos y omisiones en la conservación 
de la biodiversidad de México, in: Capital Natural de México, Vol. II: Estado de Conservación y Tendencias de Cambio. Conabio, México, pp. 651-718.

Koleff, P., Urquiza-Haas, T., 2011. Planeación para la conservación de la biodiversidad terrestre en México: retos en un país megadiverso. Comisión Nacional para el Conocimiento y Uso de la Biodiversidad-Comisión Nacional de Áreas Naturales Protegidas, México.

Lawler, J.J., Aukema, J.E., Grant, J.B., Halpern, S., Kareiva, P., Nelson, C.R., Ohleth, K., Olden, J.D., Schlaepfer, M.A., Silliman, B.R., Zaradic, P., 2006. Conservation science: a 20-year report card. Front. Ecol. Environ. 4, 473-480.

Llorente-Bousquets, J., Michán, L., González, J., Sosa, J., 2008. Desarrollo y situación del conocimiento de las especies, in: Conabio (Ed.), Capital Natural de México, Vol. I: Conocimiento Actual de La Biodiversidad. Comisión Nacional para el Conocimiento y Uso de la Biodiversidad, México D.F., México, pp. 193-214.

Llorente-Bousquets, J., Ocegueda, S., 2008. Estado del conocimiento de la biota, in: Conabio (Ed.), Capital Natural de México, Vol. I: Conocimiento Actual de La Biodiversidad. Comisión Nacional para el Conocimiento y Uso de la Biodiversidad, México D.F., México, pp. 283-322.

Maddock A.H., Samways, M.J., 2000. Planning for biodiversity conservation based on the knowledge of biologists. Biodiv. Conserv. 9, 1153-1169.

Mittermeier, R.A., Carr, J.L., Swingland, I.R., Werner, T.B., MAst, R.B., 1992. Conservation of amphibians and reptiles, in: Adler, K. (Ed.), Herpetology: Current Research on the Biology of Amphibians and Reptiles. Proceedings of the First World Congress of Herpetology. Society for the study of amphibians and reptiles, Oxford, pp. 59-80.

Naranjo, E.J., Dirzo, R., 2009. Impacto de los factores antropogénicos de afectación directa a las poblaciones silvestres de flora y fauna, in: Conabio (Ed.), Capital Natural de México, Vol. II: Estado de Conservación y Tendencias de Cambio. Comisión Nacional para el Conocimiento y Uso de la Biodiversidad, México, pp. 247-276.

Ortega-Rubio, A., Arguelles-Méndez, C., 1999. Management plans for natural protected areas in Mexico: La Sierra de la Laguna case study. Int. J. of Sust. Dev. World Ecology 6, 68-75.

Pino-Del-Carpio, A., Villarroya, A., Ariño, A.H., Puig, J., Miranda, R., 2011. Communication gaps in knowledge of freshwater fish biodiversity: implications for the management and conservation of Mexican biosphere reserves. J. Fish Biol. 79, $1563-1591$.

Rands, M.R.W., Adams, W.M., Bennun, L., Butchart, S.H.M., Clements, A., Coomes, D., Entwistle, A., Hodge, I., Kapos, V., Scharlemann, J.P.W., Sutherland, W.J., Vira, B., 2010. Biodiversity conservation: challenges beyond 2010. Science 329, 1298-303.

Saunders, D.L., Meeuwig, J.J., Vincent, A.C.J., 2002. Freshwater Protected Areas: Strategies for Conservation. Conserv. Biol. 16, 30-41.

Soberón, J., Jiménez, R., Golubov, J., Koleff, P., 2007. Assessing completeness of biodiversity databases at different spatial scales. Ecography 30, 152-160. 
Stuart, S.N., Chanson, J.S., Cox, N.A., Young, B.E., Rodrigues, A.S.L., Fischman, D.L., Waller, R.W., 2004. Status and trends of amphibian declines and extinctions worldwide. Science 306, 1783-6.

Thomson Scientific, 2009. ISI Web of Knowledge [WWW Document]. URL http://www.accesowok.fecyt.es/login/

Toledo, V., 2010. La Biodiversidad de México: inventarios, manejos, usos, informática, conservación e importancia cultural. Fondo de Cultura Económica, México.

Uetz, P., Hosek, J. (eds), 2007. The Reptile Database. Elaphe 15, 22-25.

UNEP, 2010. UNEP/CBD/BS/COP- MOP/2/WG.1/CRP.1 Updating and revision of the Strategic Plan for the post-2010 period. Convention on Biological Diversity. URL: http://www.cbd.int/cop/cop- 10/doc/advance-final-unedited-texts/advanceunedited-version-strategic-plan-footnote-en.doc.

UNESCO, 1996. Reservas de biosfera: La Estrategia de Sevilla y el Marco Estatutario de la Red Mundial.

UNESCO, 2011. Ecological Sciences for Sustainable Development - Biosphere Reserves [WWW Document]. URL http://www.unesco.org/new/en/naturalsciences/environment/ecological-sciences/biosphere-reserves/

Urbina-Cardona, J.N., 2008. Conservation of Neotropical herpetofauna: research trends and challenges. Trop. Conserv. Sci. 1, 359-375.

Williams, B.K., 2003. Policy, Research, and Adaptive Management in Avian Conservation. The Auk 120, 212-217.

Wilson, D.E., Reeder, D.M., 2005. Mammal species of the world. A taxonomic and geographic reference, third edit. ed. John Hopkins University press, Baltimore. 


\section{Figures}

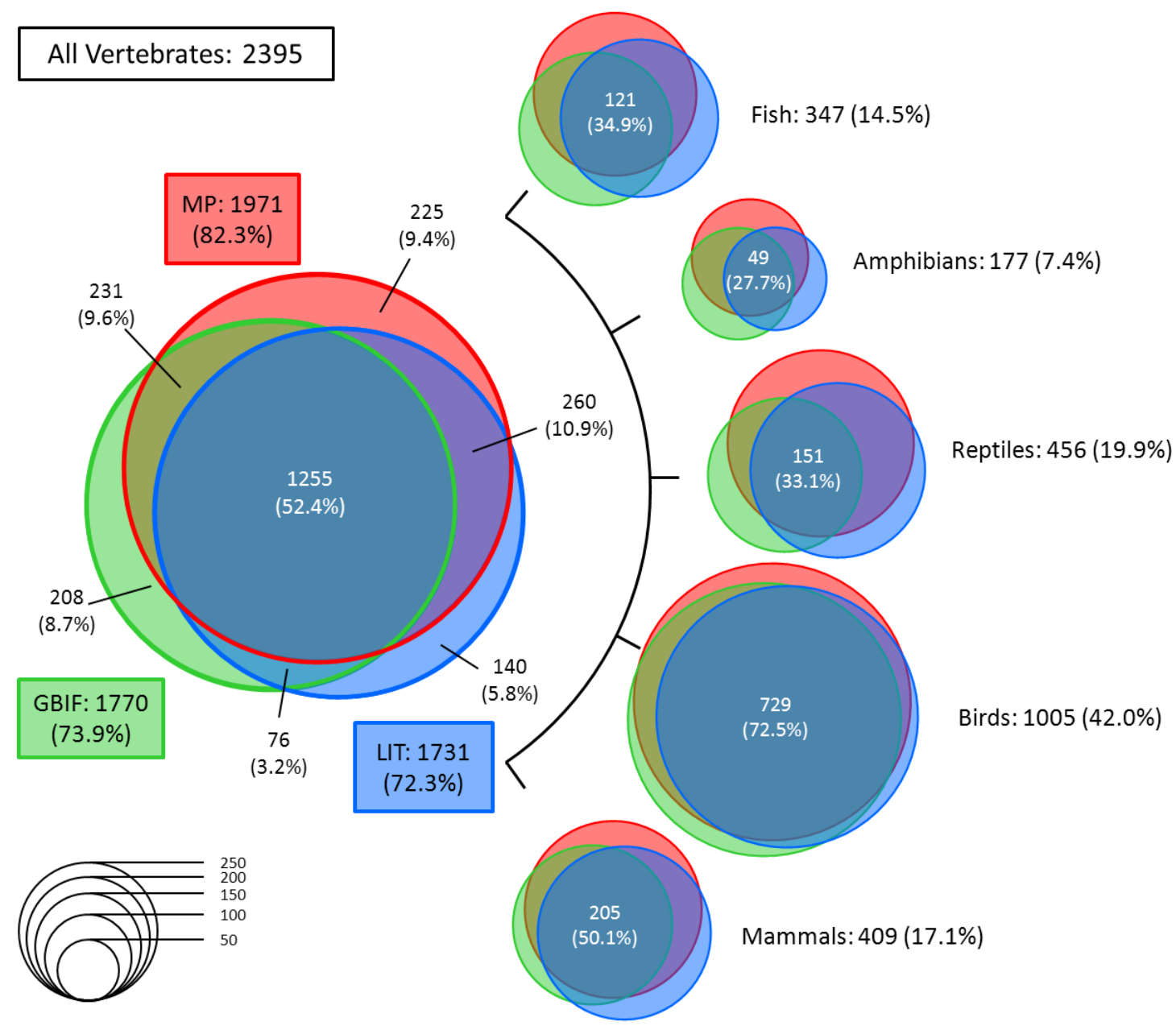

Figure1: Total number of species in the studied biosphere reserves according to the vertebrate group and the source of information. MP: management plans, GBIF: global biodiversity information facility, LIT: scientific literature. Areas are proportional to the number of species. 
Number of species

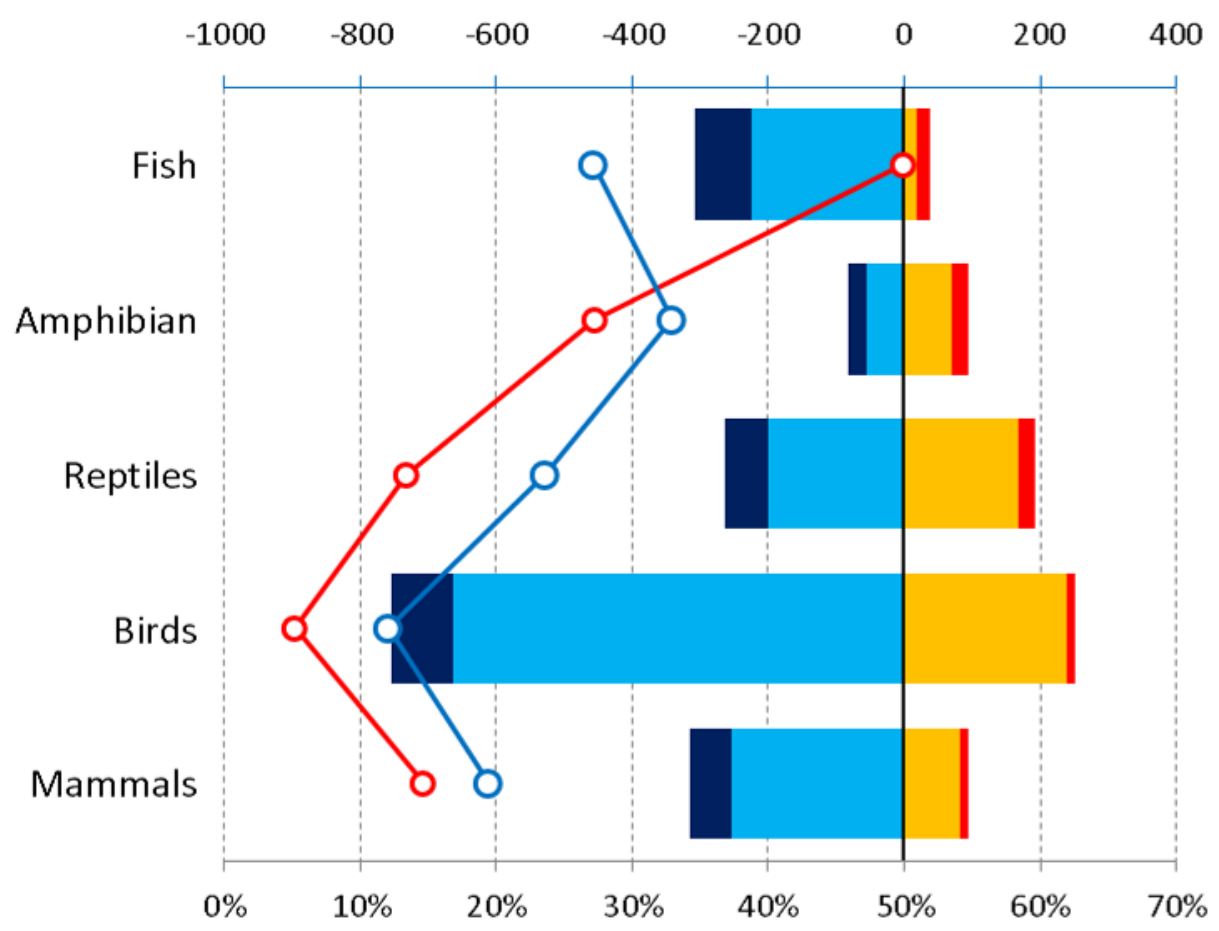

Percent of species

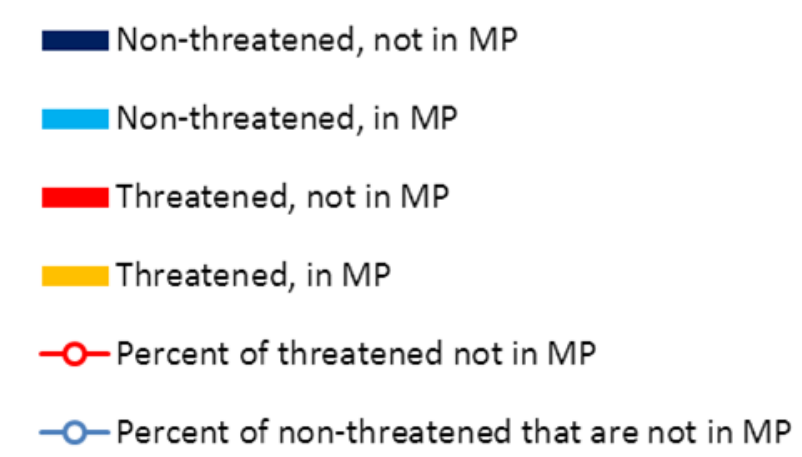

Figure 2: Threat status of species found in the management plans (MP) of Mexican Biosphere Reserves. 